\title{
Individual investment accounts as a tool for investing in the financial market: the value-based legal approach
}

\author{
Larisa Yuryevna Dobrynina* \\ Ural State Legal University, 21, Komsomolskay st., Ekaterinburg, 620137, Russia
}

\begin{abstract}
The article is a comprehensive study of the legal regime of Russian individual investment accounts (IIA) as a financial tool intended only for citizens, taking into account the existing legislation which deserves special attention, since it reflects key problems of the financial market. Under the sanctions imposed on the Russian Federation and economic recovery after the negative impact of the COVID-19 pandemic, the national political and legal concept is aimed at involving the population in the investment process and ensuring sustainable development. The scientific and practical value of the research results is due to the development of civil legal ideas about the legal mechanism of individual investment accounts as an instrument of tax policy, taking into account the aspects of administrative and labor law and the impact of digital technologies. The legal relations between professional participants in the securities market and citizens associated with IIAs are analyzed taking into account the methods of gaining income (value), including tax advantages. The novelty of the study is due to the systematic analysis of the dynamics of legal relations and administrative barriers which reduce the economic efficiency of IIAs. A number of problems related to the lack of comprehensive legal protection of the rights and interests of citizens-investors have been identified (safety of assets on these accounts).
\end{abstract}

\section{Introduction}

Law is a socially useful, effective means of social development [1]. Historical and civilizational development enriches the meaning of legal structures, creates a need for constant improvement of practical and effective forms of positive law, which are far from ideal [2].

In the era of revolutionary development of new technologies, cross-border financial services and new global regulation approaches, the problem of investment is key for any economic sector. The sustainable growth of the Russian economy, financial stability and living standards of the population depend on the effectiveness of measures of state regulation of the financial market. The value result of the financial market is efficient allocation of monetary resources and associated risks, fair prices for assets and sustainable economic development of society.

The legal regulation and development of the financial market that generates cash flows and represents a space for organized and unorganized transactions with financial instruments containing monetary value should take into account international trends. By streamlining the economic processes with the help of legal regulation, the Russian legislator solves urgent economic problems, creates additional opportunities for the finance industry and social spheres [3].

To fulfill these strategic objectives, there are different general (civil and tax regulation) and special measures (the legal status of professional participants in the securities market, combating money laundering in a criminal way, etc.). The government is taking measures aimed at stimulating investment activities, fixing new models of financial instruments and behavior models in the legal framework, providing subjects with new opportunities for generating income (value), including in digital form. The financial market develops and improves through the prism of legal regulation of the market relations, creating a new digital reality.

Over the past decades, Russia has accumulated investment experience, changed the strategy and tactics of managing investment processes [4]. However, the international debt market was closed for Russian participants in the spring of 2014. Due to the aggravation of the political crisis in Ukraine, the cost of external borrowing for Russian banks and companies has increased [5]. Under the economic sanctions imposed by the US, EU, Canada, Japan and other countries, the problem of intensive development of a self-sufficient securities market is especially acute [6].

The participation of citizens in the financial market is an indicator of maturity of the financial market, which transforms individual savings into long-term and sustainable investments.

In order to involve citizens in the stock market activities, the legislator and the Bank of Russia are taking measures to stimulate individuals to place their funds on the securities market for the purpose of longterm investment and diversification of investments, in

\footnotetext{
Corresponding author: dovre@yandex.ru
} 
particular, by implementing new financial instruments intended for citizens.

For a long time, income from long-term investments of citizens was exempt from taxation (the sale of residential real estate, which was owned for more than three years; bank deposit interests within the key rate of the Bank of Russia increased by 5\%); therefore, from a tax point of view, investments in securities were considered to be less attractive than other types of investments. To equalize tax conditions and stimulate citizens' investment in financial market instruments, a different direction was chosen [7]; in 2015, individual investment accounts (IIA) were implemented. The concept of investment tax deduction was developed to create a new socio-economic stratum - private investors [8]. Amendments were made to the Federal Law "On the Securities Market" No. 39-FZ of 04.22.1996 and the Tax Code of the Russian Federation.

According to the Moscow Exchange, if in 2020 during the COVID-19 pandemic, Russian citizens participants in the financial market opened 1.35 million IIAs compared to 1.65 million in the previous five years, in 2021, their number increased up to 3.8 million.

The legal structure of individual investment accounts is not new on a global scale. Countries that play a leading role in the international financial market are involving individuals into the investment process through the implementation of relevant government programs. In the United States, a group of Individual Retirement Accounts (IRA) is used. It implies a number of investment benefits for citizens, as well as the absence of income tax [9]. In 1999 in the UK, several types of individual savings accounts (ISA) were used ; their funds are not subject to income tax or capital gains tax [10]. Since 1992 France has had the Plan d'Epargne en Actions (PEA), according to which $75 \%$ of funds must be invested in shares of EU countries for at least 5 years in order to receive tax benefits. In Japan, since 2014, citizens have the right to open special tax-free accounts for small investments and financial instruments related to investments Nippon Individual Savings Account (NISA) ; in Canada, tax-free Savings Accounts (TSFA) are tax-free.

\section{Materials and methods}

The individual investment account (IIA) is an internal account designed for separate accounting of funds and securities of a citizen, and obligations under contracts concluded by the client (part 1 of Article 10.2-1 of the Law on Securities Market). IIS allows investors to form a diversified investment portfolio of investments, including through the purchase of securities.

The account is opened by a broker or trustee under the brokerage agreement or securities trust agreement agreements for maintaining individual investment accounts. The citizen has the right to conclude an agreement for the maintenance of an IIA only with a professional participant in the securities market licensed by the Central Bank of Russia (Art. 3 and Art. 5 of the Law on Securities Market). Agreements for maintaining an individual investment account are concluded with individuals in the manner prescribed by Art. 428 of the Civil Code of the Russian Federation by signing and sending an acceptance of the standard IIA maintenance agreement with appendices (service regulations, regulations for an electronic document management system, risk notifications, tariffs for brokerage services or trustee services management) to the broker.

In the context of the ongoing COVID-19 pandemic, the simplified identification of investors using mobile applications and investment platforms through predetermined the main influx of retail investors into the financial market segment, online through digital channels.

Individual investment accounts are internal accounts of a broker or trustee, on which cash, securities and other financial instruments purchased by citizens are recorded. The accounts are not fully subject to the Civil Code of the Russian Federation (part two of January 26, 1996, No. 14-FZ (as amended)) and regulations of the Bank of Russia governing the opening, maintenance and closure of bank accounts, since the IIA is not a bank account and has a special legal regime. However, for the purposes of state control, the tax agent is obliged to report the opening or closing of an IIA to the tax authority within 3 days via telecommunication channels (part 15 of article 226.1 of the Tax Code of the Russian Federation, Order of the Federal Tax Service of Russia dated December 15, 2014, No. MMB-7-11 / 645 @).

The agreement for opening an individual investment account provides the agents with the opportunity to perform certain actions with assets and serves as a means of securing the income received.

To make the high-risk assets of the securities market more attractive and stimulate the investment activity of individuals, the legislator has developed a special mechanism for generating returns on individual investment accounts.

First, for securities purchased under the IIA maintenance agreements, clients are paid income from securities operations (dividends, coupon bonds income, income from the sale or redemption of securities, etc.) and other financial instruments. Based on the results of the tax period, a client can receive both positive and negative financial results from investing IIA funds in financial instruments.

When concluding an agreement for maintaining the IIA with a broker, investors purchase securities independently. The broker provides a client with access to electronic exchange trading conducted in the form of an anonymous auction. An individual can invest money in the financial market using the individual investment account, making transactions with equity securities, including those of foreign issuers (Moscow Exchange MICEX-RTS, St. Petersburg Exchange, etc.), other financial instruments, purchase foreign currency and securities denominated in foreign currency, if these transactions are carried out within the Russian legislation. In addition, they can invest in derivative financial instruments that are officially traded on the Russian stock exchange.

The IIA management agreement with a trustee 
implies that this participant concludes transactions on his own behalf, but in the interests of the beneficiary. There are several management strategies, which range from "conservative" ones, which involve investing money in highly reliable stocks and bonds, and obtaining a stable but low income with low risk to "high-risk" ones, whose purpose is to conduct risky speculative transactions in the stock market.

Second, when determining the size of the tax base (part 3 of article 210 and article 214.1 of the Tax Code of the Russian Federation), the owner of an individual investment account has the right to receive a stateguaranteed investment tax deduction in the amount of money deposited on the IIA or in the amount of the investment income (part 3 of article 219.1 of the Tax Code of the Russian Federation).

The government provides a citizen with one or two options for tax deduction: refund of personal income tax (personal income tax) at a rate of $13 \%$ from the contribution amount up to 400 thousand rubles or the absence of personal income tax for investment income received from account transactions when it is closed after three years. Depending on the option chosen, the Bank of Russia classifies all IIA into type "A" and type "B". There is no combination of various tax deductions for one IIA.

The tax deduction for A IIA is provided to a taxpayer who has taxable income at a rate of $13 \%$ and submitted a tax return application (Articles 80, 229, Clause 2, Part 3, Article 219.1 of the Tax Code of the Russian Federation) and a document confirming the fact of crediting funds to the IIS (Letter of the Federal Tax Service of the Russian Federation of May 27, 2015, No. BS-4-11 / 8977 @). Since the investment tax deduction is the right of taxpayers, the tax agent does not provide an investment tax deduction without the written consent of the taxpayer (Letter of the Ministry of Finance of the Russian Federation of November 19, 2018 No. 03-04-06 / 83241).

In new laws, there more advanced techniques of legal technology [1]. Since 2021, the legislator has provided for an additional measure to encourage investment by creating an electronic service that involves an alternative simplified procedure for obtaining tax deductions (Federal Law of 20.04.2021 No. 100-FZ "On Amendments to Part One and the second of the Tax Code of the Russian Federation "). Taxpayers who have a personal account on the website of the Federal Tax Service of Russia (www.nalog.ru) have the right to receive tax deductions in a shorter period (45 days) by applying through the taxpayer's personal account; all other documents are submitted to the tax authority by a broker or trustee, with whom citizens have entered into IIA management agreements.

The tax deduction for "B" IIA in the form of exemption from personal income tax is provided at the end of the contract with the payment of income through a broker or a trustee (clause 3, part 1 of article 219.1 of the Tax Code of the Russian Federation).

The basis for the legal relations between a citizen and a professional participant in the securities market is a civil contract, which can be changed or terminated by mutual agreement of the parties. In particular, the court recognized the right to terminate the contract at any time without giving reasons, notifying the other party in writing at least 30 calendar days before the day of termination (Decision of the Ordzhonikidze District Court, Magnitogorsk, Chelyabinsk Region, February 16, 2018, case No. 2-544 / 2018). However, such legal actions have certain tax consequences. In case of termination of the IIA management agreement before the expiration of 3 years from the date of its conclusion by the taxpayer (except for the reasons beyond the control of the parties), the amount of tax deductions and the amount of penalty should be paid to the budget as unjust enrichment (Decision of the Taganrog City Court of the Rostov Region of May 14, 2019 No. in case No. 2-2063 / 2019). The IIA owner is obliged to submit revised tax returns immediately after the early closure of the investment account.

In the event of death of the IIA owner who sent a tax return application and did not manage to receive the tax deduction, this amount must be included in the hereditary mass (Decision of the Uraysk City Court (Khanty-Mansiysk Autonomous Okrug-Yugra) of January 23, 2020, case No. 2-29 / 2020).

\section{Results and Discussion}

To achieve a social effect from the use of IIAs, the legislator has established a special legal regime, creating a special procedure within the general legal regulation, characterized by a combination of permissions, prohibitions and positive obligations [11], which determines the presence of a number of conditions for opening these accounts, investing funds and ways to generate income (value):

First, IIAs are opened only for citizens, including individual entrepreneurs, - tax residents of the Russian Federation, which are recognized as individuals who are actually in the Russian Federation for at least 183 calendar days within 12 consecutive months (clause 2 of Article 207 of the Tax Code of the Russian Federation). In cases provided for in Chapter 23 of the Tax Code of the Russian Federation, the personal income is taxed based on the tax status. At the end of the tax period, the tax status is determined for the tax period.

Second, the IIA agreement can be opened only in rubles (part 8 of article 10.2-1 of the Law on Securities Market). It is allowed to purchase securities and derivative financial instruments and foreign exchange funds.

Third, the client has the right to have only one IIA management agreement. A broker or trustee enters into an agreement if an individual has declared that he does not have a similar agreement with another professional participant in the securities market (article 219.1 of the Tax Code of the Russian Federation, part 2 of article 10.2-1 of the Law on the Securities Market). The professional participant has the right to check the IIA in order to exclude its duplication.

The tax deduction is provided to the taxpayer, provided that during the IIA management, the taxpayer 
did not have similar contracts, except for cases of termination of the contract with the transfer of all assets to another individual investment account (Letter of the Ministry of Finance of the Russian Federation of October 31, 2016 No. 03-04-06 / 63687) In the latter case, this transfer is a transaction for the transfer of all rights and obligations to another person (Article 392.3 of the Civil Code of the Russian Federation).

In the event of dishonest behavior, the investment tax deduction is not provided (Letter of the Federal Tax Service of Russia No. BS-19-11/22@ of 21.01.2021); if this deduction was granted, the amount of tax deductions is subject to recovery and payment to the budget at the request of the Federal Tax Service of Russia, with the collection of the corresponding amounts of penalties from the taxpayer, or by a court decision using the rules on unjust enrichment (Article 1102 of the Civil Code of the Russian Federation) (Decision of the Moscow District Court of Cheboksary (Chuvash Republic) dated July 30, 2020, case No. 2-1826 / 2020). The fact that funds were not credited to such open accounts has no legal significance, since the IIA management agreement is considered to be concluded from the moment the account holder receives the acceptance; besides, the current legislation does not make it possible to receive an investment tax deduction depending on the absence of cash flow on individual investment accounts opened during the period of validity of this agreement (Decision of the Soviet District Court of Bryansk (Bryansk Region) dated July 12, 2019, case No. 2A-4265/2019).

This does not exclude the conclusion by an individual with one broker or trustee of several contracts of a type other than the IIA, for each of which the broker or trustee can calculate the amount of tax.

Fourth, within the IIA management agreement, the client can annually deposit funds to the account in the amount not exceeding 1 million rubles during the calendar year (part 8 of article 10.2-1 of the Law on the Securities Market). However, the tax deduction for the A type IIA is returned to the citizen only in the amount of 52 thousand rubles with a maximum contribution amount of 400 thousand rubles annually.

Fifth, the term of an individual investment account is legally limited, which cannot exceed three years (clause 1, part 4, article 219.1 of the Tax Code of the Russian Federation).

Sixth, the account operations are specified: partial withdrawal of funds or securities, return of funds and securities, or their transfer to another professional participant in the securities market without termination of the IIA management agreement is not allowed. Nevertheless, the transfer of payments to the current and other accounts (for example, when the depositary transfers income and other monetary payments on securities to the depositor) without crediting them to an individual investment account is not a basis for terminating the contract for maintaining the IIA (part 3 of Art. 10.2-1 of the Law on Securities Market, Letter of the Central Bank of the Russian Federation dated September 23, 2015 No. 55-5-1 / 2249).

Seventh, in order to independently invest in complex financial instruments (investment shares of mutual investment funds, Eurobonds, structured notes, depositary receipts, etc.), the client must obtain the status of a qualified investor in accordance with the Russian legislation (clause 4 of article 51.2 of the Law on Securities Market, subclause 2.1.1-2.1.5 of the Bank of Russia Ordinance No. 3629-U dated April 29, 2015 "On the recognition of persons as qualified investors and the procedure for maintaining the register of persons, recognized by qualified investors ").

Eighth, the Russian legislation provides for restrictions on the use of funds, securities and financial instruments that are accounted for in the individual investment account, which implies:

a) cash and stock assets on the IIA are intended only for the fulfillment of obligations arising on the basis of the IIA management agreement and cannot be used for other purposes on the basis of other agreements, including those concluded with a forex dealer (part 6-7 Article 10.2-1 of the Law on the Securities Market).

b) when placing funds in trust with banks, the amount of deposits cannot exceed $15 \%$ of the amount of funds originally deposited on the IIA. This limitation is due to the fact that if a professional participant places part of the funds on the IIA, these investments are not protected by the deposit insurance system (part 9 of article 10.2-1 of the Law on Securities Market).

c) acquisition and placement of federal loan bonds on the individual investment account are not allowed (Order of the Ministry of Finance of the Russian Federation of 03/15/2017 No. 38n).

From an axiological point of view, one of the important features of legal development is differentiated regulation of the social relations. Legal norms regulate the relations between participants in the financial markets and establish the framework within which the rights can be exercised and duties must be fulfilled. In this regard, when exercising rights and obligations by IIA owners, it is important to take into account that administrative and labor legislation provides for additional public obligations and prohibitions:

- For state and municipal employees - annual provision of information about their income, property and property obligations (Federal Law of December 25, 2008 No. 273-FZ (as amended) "On Combating Corruption"; Federal Law of December 03, 2012 No. 230-FZ "On control over the compliance of expenses of persons holding public office and other persons with income"). These subjects are obliged to submit information on income, property and property obligations received under the IIA management agreement (Decree of the President of the Russian Federation of 06/23/2014 city No. 460). In cases of noncompliance with the legislative restrictions and prohibitions, the employer has the right to take a disciplinary measure from among those provided for by law.

- For a number of persons from among state, municipal employees, their spouses and minor children, it is prohibited to have rights under foreign financial instruments, which is associated with their special public status (Federal Law dated 07.05.2013 No. 79-FZ "On the prohibition for some categories of persons to open and 
have accounts (deposits), keep cash and valuables in foreign banks located outside the Russian Federation, own and (or) use foreign financial instruments"). At the same time, the IIA management agreement allows for the possibility of purchasing foreign securities through the Russian trade organizer at the expense of the property in the individual investment account (paragraph 2, part 9, article 10.2-1 of the Law on Securities Market). In order to prevent the violation of these prohibitions when opening an individual investment account, the persons subject to the above prohibitions should include a clause prohibiting the acquisition of foreign securities and derivative financial instruments.

- The legal relationship of opening, maintaining and closing IIAs is regulated by Federal Law of 07.08.2001, No. 115-FZ "On Counteraction to Legalization (Laundering) of Criminally Obtained Incomes and Financing of Terrorism", which establishes financial measures to combat money laundering. In one of the court cases, the bank refused to fulfill the client's orders to carry out operations for the withdrawal of funds from the deposit and transfer of these funds to the IIA within the brokerage agreement, guided by this law and following the Internal Control Rules. The court established that the bank had the right to request information from the client in order to establish the source of the funds (Decision of the Leninsky District Court of Tambov dated 12.07.2017, case No. 2 1448/17).

Thus, the relations that develop in the IIA management are legal relations, including civil and administrative legal relations (including tax), which arise, change and terminate in connection with the possession and disposal of money, valuable securities and financial instruments.

According to the Bank of Russia, if in 2018 the amount of funds on individual investment accounts was 81 billion rubles, in 2019 the volume of assets on IIAs reached 143.8 billion rubles, of which 95.4 billion rubles were on brokerage IIAs and 48.4 billion rubles - on IIAs; in 2020, the amount of funds was 246 billion rubles. Individual investment accounts account for a significant share of all registered retail investor brokerage accounts. Nevertheless, the number of IIA owners is only $2 \%$ of the population. In the unstable post-pandemic and external economic conditions, the Russian financial market is still characterized by a rather low activity of the population.

The determining factor is the fact that citizens of the Russian Federation prefer opening bank deposits, which are easy to use and not risky (all deposits are insured in the amount of $\$ 1.4$ million. rubles). To improve the IIA system and the retail investment market, the Bank of Russia initiated a gradual reduction in the key rate, which decreased profitability of deposits and caused an influx of new investors into the stock market.

The decisive deterrent negative circumstance is the total debt load, the absence of temporarily free savings, the shift of the social perspective to consumption, which prevents citizens of from opening individual investment accounts [12].

Based on the assessmenrt of the current state of the financial market and behavioral models, it can be argued that more and more long-term investors are entering into the market, preferring A type IIAs and passive strategies. Moreover, the bulk of IIA assets are placed in financial instruments with minimal profitability and risks (Russian stocks, government and municipal bonds, some types of investment shares). To make the long-term business model embodied in Type $B$ investment accounts economically more attractive to retail investors, the government has been discussing a gradual reduction on the opportunity for investors to open Type A IIAs which are tax-deductible. The financial market mega-regulator has offered less radical concepts for the development of the type B IIA system: exemption from taxation of the entire amount upon closing an account, an increase in the maximum amount of a contribution to the second type IIA, lifting the ban on opening only one IIA and granting the right to withdraw funds from accounts without closing them.

The population remains a donor, and the real sector of the economy isa recipient of resources in the Russian financial market [13]. Since funds in the IIAs must be reinvested every three years, another project initiated by the Bank of Russia and supported by the National Association of Stock Market Participants involves the creation of a new type of individual investment accounts which do not limit the amount of invested funds and establish a 10-year limit. Since the citizen is an economically weaker party, it is proposed to legislatively determine a number of additional areas for the targeted spending of funds, in particular, for the purchase of housing, payment for education, insurance premiums and partial early withdrawal of funds without limiting the amount. This will allow citizens to independently choose investment strategies and service conditions and also contribute to the development of competition in the financial industry.

Since in 2021, the share of IIA investment in nonresident instruments reached $15 \%$, in order to strengthen the financial sovereignty [14], the Bank of Russia offerred to provide tax incentives for individual investment accounts only if investments are made in Russian financial instruments.

In terms of values, the law plays an irreplaceable role in strengthening citizens' confidence in securities and stock market transactions. The determinant of preferences of investors in choosing conservative strategies and focusing them on the type A IIA is associated with the fact that the mechanism for protecting the rights of investors involves the use of methods of legal protection provided for by the Civil Code of the Russian Federation. Transactions on the stock exchange market refer to aleatory transactions conducted by their participants at their own risk (clause 2 of article 1062 of the Civil Code of the Russian Federation). The investment activity of citizens within the IIA is associated with the uncertainty in obtaining the expected financial result based on the results of investment activities, the possibility of an event that entails the non-receipt of the expected income and the loss of part or all of the amount of funds invested (Decision Dalmatovsky District Court of the Kurgan 
Region dated 02.14.2019, case No. 2-31 / 2019).

Retail investors are subject to Federal Law No. 46FZ dated 05.03.1999 "On the Protection of the Rights and Legal Interests of Investors in the Securities Market". It establishes the protection of rights of individuals whose investment objects are equity securities. Nevertheless, the range of methods of protection against the investment risks listed in this law is narrow and involves the creation of compensation and other funds for compensating for the damage as a result of activities of professional participants in the securities market.

There is a financial ombudsman as a mandatory pretrial instance for resolving disputes between consumers of financial services and financial organizations. However, there are a number of formal restrictions due to which the financial ombudsman cannot consider some applications from citizens, in particular, applications for the collection of monetary amounts under the IIA in the amount of over 500 thousand rubles (part 2 of article 16 of the Federal Law of 04.06.2018 No. 123-FZ "On the Commissioner for the Rights of Consumers of Financial Services").

There are no methods of protecting the rights of individual investors such as compensation for moral damage and court fines, since the Law "On Protection of Consumer Rights" is not applicable. This is confirmed by judicial practice. Due to the risky nature of securities activities, they cannot be recognized as activities aimed at meeting personal (household) needs. According to the court, since personal non-property rights were not violated by the broker, the claims for recovery of compensation for moral damage cannot be satisfied (Decision of the Leninsky District Court of Ulyanovsk, Ulyanovsk Region dated 05.02.2019 in the case No. 2452 / 2019).

\section{Conclusion}

Legal rules embodying the principles of justice and moral principles implies a system of subjective rights, which is a legal value for investors. An important factor of successful reforms implemented in the financial market is the consistency of legal regulation and qualitative characteristics of legislation that ensure a balance of interests of its participants, the presence of efficiently working institutions and mechanisms aimed at protecting investments, the rights and legitimate interests of investors.

According to the Bank of Russia, in the Russian securities market, a non-complete list of methods for protecting investors is used. There is no mechanism for ensuring the safety of citizens' investments in the securities market, which determines the low interest of potential investors in purchasing instruments of the Russian stock market intended for long-term investment.

Since in the Russian Federation, citizens need more protection, draft federal law No. 76910-7 "On insurance of investments in individual investment accounts" was submitted to the State Duma (Resolution of the State Duma Federal Tax Service of the Russian Federation dated June 21, 2017 No. 1787-7 GD). It provides for the creation of an investment insurance fund at the expense of contributions from professional participants in the securities market. By analogy with bank deposits, the maximum amount of insurance payments is supposed to be 1 million 400 thousand rubles.

During the pandemic, the termination of activities of enterprises in the real sector of the economy constrained cash flows in the financial sector, many of whose participants were not able to independently regulate transactions in the money market [15]. The Russian Federation seeks to implement advanced international practices for protecting the rights of investors, taking into account the positive foreign experience of anti-crisis regulation of the financial market. This trend is traced in the European Union, where in 1997, Directive 97/9 / EC "On compensation systems for the protection of investors' rights" was adopted. It provides for the creation of compensation mechanismss; if the investment company is unable to meet its obligations to the client, the minimum compensation payment is 20,000 EUR. The Russian legislator takes into account various business models of world financial institutions and international experience; therefore, the creation of optimal conditions for individual investment accounts, the expansion of functions of these financial products and the inflow of investments into the national economy are one of the key directions for the development of the internal market.

These are the main legal features of the Russian mechanism of individual investment accounts in the new economic conditions, in which modern law is being transformed, improved and acquires new value characteristics, adapting to the current challenges in order to construct the reality of the financial market.

\section{References}

1. S.S. Alekseev, The social value of law in Soviet society (Moscow: Legal lit., Moscow, 1971)

2. M.N. Sadchikov, E.V. Pokachalova, O.Y. Bakaeva, M.B. Razgildieva, Legal Support of State Tax Sovereignty: Paradigm Change, Advances in Social Science, Education and Humanities Research, 498 (2020). DOI: https://doi.org/10.2991/assehr.k. 201205.055

3. A.V. Mayfat, Investing: methods, risks, subjects (Statute, Moscow, 2020)

4. S.A. Sokurov, Investment model of foreign countries: the possibility of succession for Russia, Business in law, 6 (2011). Retrieved from: https://elibrary.ru/item.asp?id=17244041

5. I.A. Balyuk, Impact of external sanctions on Russian debt policy, Economics, taxes \& law, 13(4), 29-43 (2020) (In Russ.). DOI: 10.26794 / 1999849X 2020-13-4-29-43

6. V.V. Papin, Overcoming the crisis processes in the Russian securities market by means of tools for individual investment accounts: abstract of candidate dissertation (Rostov-on-Don, 2016) 
7. A. Speransky, Maintaining individual investment accounts, Accounting and banks, 11 (November 2014)

8. D.I. Yakovlev, Individual investment account: problems of legal regulation and development prospects, Financial Law, 4 (2019)

9. A. Kapteyn, C. Panis, The size and composition of wealth holdings in the United States, Italy, and the Netherlands (2003). Retrieved from: https://www.nber.org/system/files/working_papers/ w10182/w10182.pdf

10. C. Emmerson, S. Tanner, A Note on the Tax Treatment of Private Pensions and Individual Savings Accounts, Fiscal Studies, 21(1) (08 May 2006). DOI : $\quad$ https://doi.org/10.1111/j.14755890.2000.tb00580.x

11. G.S. Belyaeva, Legal regime: concept and characteristics, Bulletin of RUDN. Series: Legal Science, 25.1 (2021)
12. E. Yakushev, In debt beyond repayment: why the population's debt burden is dangerous for the state. (July 05, 2019). Retrieved from: https://www.forbes.ru/finansy-i-investicii/379435-vneoplatnom-dolgu-pochemu-zakreditovannostnaseleniya-opasna-dlya

13. Y.S. Evlakhova, The impact of digitalization on the population in the Russian financial market, Economics, taxes \& law, 13(3), 80-90 (2020) (In Russ.). DOI: 10.26794/1999-849X 2020-13-3-80-90

14. V.A. Chernov, Social and financial conditions for achieving sustainable innovation development, Economics, taxes \& law, 14(2), 55-63 (2021) (In Russ.). DOI: 10.26794/1999-849X-2021-14-2-55-63

15. O.Y. Donetskova, L.M. Sadykova, E.V. Korobeynikova, The impact of crises on the activities of financial intermediaries in Russia, Economics, taxes \& law, 14(1), 61-70 (2021) (In Russ.). DOI: 10.26794/1999-849X-2021-14-1-61-70 